\title{
Textual signs and economic signals in The Merry Wives of Windsor
}

\section{Arthur F. Kinney}

\section{(2) OpenEdition}

\section{Journals}

\section{Electronic version}

URL: http://journals.openedition.org/shakespeare/1246

DOI: 10.4000/shakespeare.1246

ISSN: 2271-6424

\section{Publisher}

Société Française Shakespeare

\section{Printed version}

Date of publication: 1 November 1993

Number of pages: 23-37

\section{Electronic reference}

Arthur F. Kinney, "Textual signs and economic signals in The Merry Wives of Windsor », Actes des congrès de la Société française Shakespeare [Online], 11 | 1993, Online since 01 January 2007,

connection on 30 April 2019. URL : http://journals.openedition.org/shakespeare/1246 ; DOI : 10.4000/ shakespeare. 1246

\footnotetext{
This text was automatically generated on 30 April 2019.

(c) SFS
} 


\section{Textual signs and economic signals in The Merry Wives of Windsor}

Arthur F. Kinney 